\title{
Beam-Powered Lunar Rover Design
}
J. E. Dagle
J. M. Bates
E. P. Coomes
M. A. Chiu
Z. I. Antoniak
R. E. Dodge
J. A. Bamberger
J. A. Wise

March 1992

Prepared for

NASA Langley Research Center under a Related Services Agreement with the U.S. Department of Energy

Contract DE-AC06-76RLO 1830

Pacific Northwest Laboratory Operated for the U.S. Department of Energy by Battelle Memorial Institute 


\title{
DISCLAIMER
}

This report was prepared as an account of work sponsored by an agency of the United States Government. Neither the United States Government nor any agency thereof, nor Battelle Memorial Institute, nor any of their employees, makes any warranty, expressed or implied, or assumes any legal liability or responsibility for the accuracy, completeness, or usefulness of any information, apparatus, product, or process disclosed, or represents that its use would not infringe privately owned rights. Reference herein to any specific commercial product, process, or service by trade name, trademark, manufacturer, or otherwise does not necessarily constitute or imply its endorsement, recommendation, or favoring by the United States Government or any agency thereof, or Battelle Memorial Institute. The views and opinions of authors expressed herein do not necessarily state or reflect those of the United States Government or any agency thereof.

\author{
PACIFIC NORTHWEST LABORATORY \\ operated by \\ BATTELLE MEMORIAL INSTITUTE \\ for the \\ UNITED STATES DEPARTMENT OF ENERGY \\ under Contract DE-AC06-76RLO 1830
}

Printed in the United States of America

\begin{abstract}
Available to DOE and DOE contractors from the
Office of Scientific and Technical Information, P.O. Box 62, Oak Ridge, TN 37831;

prices availabl: from (615) 576-8401. FTS 626-8401.
\end{abstract}

Available to the public from the National Technical Information Service,

U.S. Department of Commerce, 5285 Port Royal Rd., Springfield, VA 22161. 
PNL -8053

DE92 011511

PNL -8053

UC -000

BEAM-POWERED LUNAR ROVER DESIGN
J. E. Dagle
E. P. Coomes
Z. I. Antoniak
J. A. Bamberger
J. M. Bates
M. A. Chiu
R. E. Dodge
J. A. Wise

March 1992

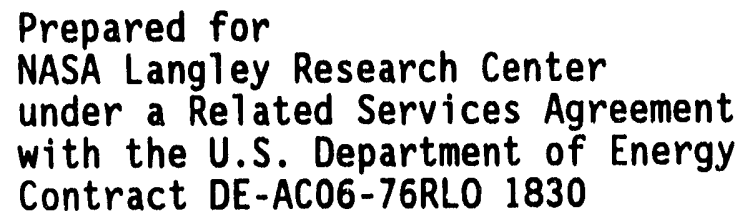

Pacific Northwest Laboratory

Richland, Washington 99352

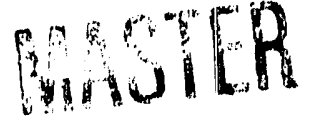




\section{EXECUTIVE SUMMARY}

Manned exploration of our nearest neighbors in the solar system is the primary goal of the Space Exploration Initiative (SEI). An integral part of any manned lunar or planetary outpost will be a system for manned excursions over the surface of the $p l a n e t$. This report presents a preliminary design for a lunar rover capable of supporting four astronauts on long-duration excursions across the lunar landscape. The distinguishing feature of this rover design is that power is provided to the rover via a laser beam from an independent orbiting power satellite. This system design provides very high power availability with minimal mass on the rover vehicle.

With this abundance of power, and with a relatively small power-system mass contained in the rover, the vehicle can perform an impressive suite of mission-related activity. The rover might be used as the first outpost for the lunar surface (i.e., a mobile base). A mobile base has the adyantage of providing extensive mission activities without the expense of establishing a fixed base. This concept has been referred to as "Rover First."

A manned rover, powered through a laser beam, has been designed for travel on the lunar surface for round-trip distances in the range of $1000 \mathrm{~km}$, although the actual distance traveled is not crucial since the propulsion system does not rely on energy storage. The life support system can support a 4-person crew for up to 30 days, and ample power is available for missionrelated activities.

The $8000-\mathrm{kg}$ rover has $30 \mathrm{~kW}$ of continuous power available via a laser transmitter located at the Earth-moon Ll libration point, about 50,000 km above the surface of the moon. This rover, wirich is designed to operate in either day or night conditions, has the flexibility to perform a variety of power-intensive missions. 


\section{CONTENTS}

EXECUTIVE SUMMARY . . . . . . . . . . . . . . . . . . . . . . iii

1.0 INTRODUCTION . . . . . . . . . . . . . . . . . . . . 1

2.0 DESIGN ASSUMPTIONS AND SUMMARY . . . . . . . . . . . . . . 3

3.0 POWER SYSTEM DESIGN . . . . . . . . . . . . . . . . . . 7

3.1 POWER REQUIREMENTS . . . . . . . . . . . . . . . . 7

3.2 LASER RECEIVER . . . . . . . . . . . . . . . . . . 8

3.3 ENERGY STORAGE . . . . . . . . . . . . . . . . 10

3.4 DISTRIBUTION SYSTEM DESIGN . . . . . . . . . . . . . 10

4.0 MECHANICAL URIVE SYSTEM DESIGN . . . . . . . . . . . . . . 13

4.1 LUNAR SOIL AND TERRAIN FEATURES . . . . . . . . . . . 13

4.2 ROVER PROPULSION REQUIREMENTS . . . . . . . . . . . . . 14

4.2.1 Acceleration ................. . 14

4.2 .2 Climbing . . . . . . . . . . . . . . . . 14

4.2.3 Horizontal Motion on Regolith ............ 14

4.2.4 Propulsion Power Requirements Summary . . . . . . . . 15

4.3 DRIVE-TRAIN DESIGN . . . . . . . . . . . . . . . 15

4.3.1 Electric Motors . . . . . . . . . . . . . 15

4.3.2 Gear Reduction................ 16

4.3.3 Braking .. . . . . . . . . . . . . . 16

4.3.4 Heat Rejection................. 16

4.3 .5 Control ..................... . 17

4.4 DRIVE-TRAIN MASS SUMMARY . . . . . . . . . . . . . . 17

5.0 HABITAT AND LIFE SUPPORT SYSTEM . . . . . . . . . . . . . . . 19

5.1 GENERAL . . . . . . . . . . . . . . . . . . 19

5.2 ATMOSPHERE . . . . . . . . . . . . . . . . . . 19

5.3 WATER . . . . . . . . . . . . . . . . . 20

5.4 FOOD . . . . . . . . . . . . . . . . . . 21

5.5 WASTE ....................... 21

5.6 TRASH . . . . . . . . . . . . . . . . . . . 22

5.7 RADIATION ENVIRONMENT AND SHIELDING . . . . . . . . . . . 22 
5.8 INTERIOR VOLUME AND SPATIAL ARRANGEMENTS . . . . . . . . 23

5.8 .1 Background . . . . . . . . . . . . . 24

5.8 .2 Basic Design . . . . . . . . . . . . 24

5.8 .3 Cockpit $(\mathrm{Cab}) \ldots \ldots \ldots . \ldots 24$

5.8 .4 Lab Space . . . . . . . . . . . . . 25

5.8 .5 Airlock ................. 26

5.8 .6 Summary . . . . . . . . . . . . . 27

6.0 CABIN HEAT REJECTION SYSTEM . . . . . . . . . . . . . . 29

6.1 DAYTIME OPERATION ................... 29

6.2 NIGHTTIME OPERATION .................... 32

6.3 EMERGENCY OPERATION .................... . . . 33

7.0 MISSION SUMMARY AND HARDWARE REQUIREMENTS ........... 35

7.1 MISSION CLASSIFICATIONS . . . . . . . . . . . . 35

7.1.1 Geophysical Investigations ........... 35

7.1.2 Geophysical Ground Sample Archival ........ 36

7.1 .3 Geophysical Mapping ............ 36

7.1.4 Lunar Environmental Monitoring . . . . . . . . . 36

7.1.5 Lunar Geoscience Measurements . . . . . . . . . 36

7.1 .6 Minirover . . . . . . . . . . . . . 36

7.1.7 Lunar Gas Extraction Experiment ......... 36

7.2 HARDWARE REQUIREMENTS ............... . . 37

7.3 IN SITU RESOURCE UTILIZATION DEMONSTRATION . . . . . . . . 37

8.0 CONCLUSIONS . . . . . . . . . . . . . . . . 39

9.0 REFERENCES . . . . . . . . . . . . . . . . . . 41

10.0 BIBLIOGRAPHY .................... 43 


\section{EIGURES}

2.1. Laser Beam-Powered Lunar Rover . . . . . . . . . . . . . . 4

2.2. Internal Cross Seciion View . . . . . . . . . . . . . . 5

3.1. Laser Receiver Schematic Diagram . . . . . . . . . . . . . 9

3.2. Power System One-Line Diagram . . . . . . . . . . . . . . . . . 11

6.1. Radiator Temperature Versus Area for Daytime Operation . . . . . 30

6.2. Radiator Temperature Versus Lunar Surface Temperature . . . . . . . 32

\section{TABLES}

2.1. Lunar Rover Design Parameters . . . . . . . . . . . . . . 3

2.2. Rover Mass Breakdown .................... 3

3.1. Power Allocation Summary .. . . . . . . . . . . . . . 7

3.2. Laser Receiver Mass Breakdown . . . . . . . . . . . . . . . . . 9

4.1. Propulsion Power Requirements . . . . . . . . . . . . . . 15

4.2. Electric Motor Specifications . . . . . . . . . . . . . . 16

4.3. Drive-Train Mass Summary .. . . . . . . . . . . . . . . 18

7.1. Mission-Related Equipment Manifest . . . . . . . . . . . . . . . 37

7.2. In Situ Resource Demonstration Activities . . . . . . . . . . 38 


\subsection{INTRODUCTION}

Providing adequate power and energy to a manned rover vehicle for exploration on the moon is a challenging endeavor. For maximum usefulness, the rover should have an extended range capability, which typically implies considerable onboard power generation or energy storage capability. The state of the art in power generation and/or energy storage devices is not optimal for an extended lunar mission and enormous mass would be required for any long mission. This problem is compounded by the long lunar day and night, which severely constrain options such as photovoltaic power production and battery storage. Radioisotope thermoelectric generators (RTGs) have been considered for an unmanned low-power $(500 \mathrm{~W}$ ) rover application on Mars (Schock et al. 1989a, 1989b). It is doubtful that the approximately $25-\mathrm{kW}$ requirement for a manned rover could be met with the low specific power of RTGs. At current specific RTG power production of about $5 \mathrm{~W} / \mathrm{kg}$, an RTG-powered lunar rover would have a power system mass in excess of $5000 \mathrm{~kg}$. The use of methanol to power a rover has also been proposed recently; a fuel/oxidizer load of $500 \mathrm{~kg}$ was expected to provide a $250-\mathrm{km}$ range on Mars and somewhat more on the moon (Clark et al. 1991). Vehicle mass was not clearly stated in the methanol use study, but an assumption of $1 \mathrm{kWh} / \mathrm{km}$ travel over Martian terrain determined fuel use.

The use of power beamed from lunar satellites to the rover has clear advantages over the conventional methods noted. There is not only a large mass saving associated with not having to produce power onboard the rover, but additional benefits accrue as well. Abundant power is available to perform a variety of missions, enhancing the capability of the rover beyond that envisioned for an initial lunar base. With the advantage of a light-weight laser to electric converter, the rover is highly maneuverable and can operate continuously in either day or night conditions.

This paper describes the design and issues associated with a $30-\mathrm{kW}$ electric laser beam-powered lunar rover. 


\subsection{DESIGN ASSUMPTIONS AND SUMMARY}

The design assumptions that are the basis for subsequent lunar rover drive system requirements and design features are provided in Table 2.1. Although the table refers to a $1000-\mathrm{km}$ range, which was an initial design parameter, the design of the lunar rover does not preclude additional range if desired. The design does not use primary energy itorage for locomotion; thus the rover can operate continuously either moving or stationary. The mission duration and crew complement, on the other hand, are critical design parameters because they drive the mass of consumable supplies and 1 ife support system requirements. The mass summary of the rover, 1isted in Table 2.2 , is derived from subsequent sections of this report.

TABLE 2.1. Lunar Rover Design Parameters

Feature
Range
Crew Number
Mission Duration
Maximum Speed
Maximum Slope (firm soil)
Design Life

\begin{tabular}{l} 
Amount \\
\hline $1000 \mathrm{~km}$ \\
$4 \mathrm{days}$ \\
$30 \mathrm{ram}$ \\
$10 \mathrm{~h}$ \\
$30^{\circ} \mathrm{hr}$ \\
$7 \mathrm{yr}$
\end{tabular}

TABLE 2.2. Rover Mass Breakdown

Component

Laser Receiver System

Energy Storage System

Power Distribution Equipment

Command, Control, Communications

Drive System

Cabin Thermal Management

Life Support Equipment

Housekeeping Equipment

Consumables

Crew

Personal Gear

EVA Suits

Radiation Shielding

Structure

Mission Hardware

Total
Mass $(\mathrm{kg})$

8000 
The rover is a cylinder $7.5 \mathrm{~m}$ long with an outside diameter of $3.2 \mathrm{~m}$. The cylinder length includes $5 \mathrm{~m}$ of laboratory workspace, and $2.5 \mathrm{~m}$ at the aft of the vehicle for extra-vehicular access (EVA) suiting operations and manipulator arm control. The driving cab is an additional $2.5 \mathrm{~m}$ in the front of the rover. A sketch of the rover is shown in Figure 2.1.

To utilize Space Station Freedom (SSF) components, the rover uses SSF international racks $1 \mathrm{~m}$ wide laid out as shown in Figure 2.2. The EVA staging area has only bottom racks (no side racks). This yields a total of 28 racks, 12 bottom racks which are suitable for storage and 16 side racks which are used for mounting hardware. The overhead space is used for liquid storage, which is also suitable for crew radiation shielding. Rack dimensions and volume requirements are further described in Section 5.0 Habitation and Life Support System.

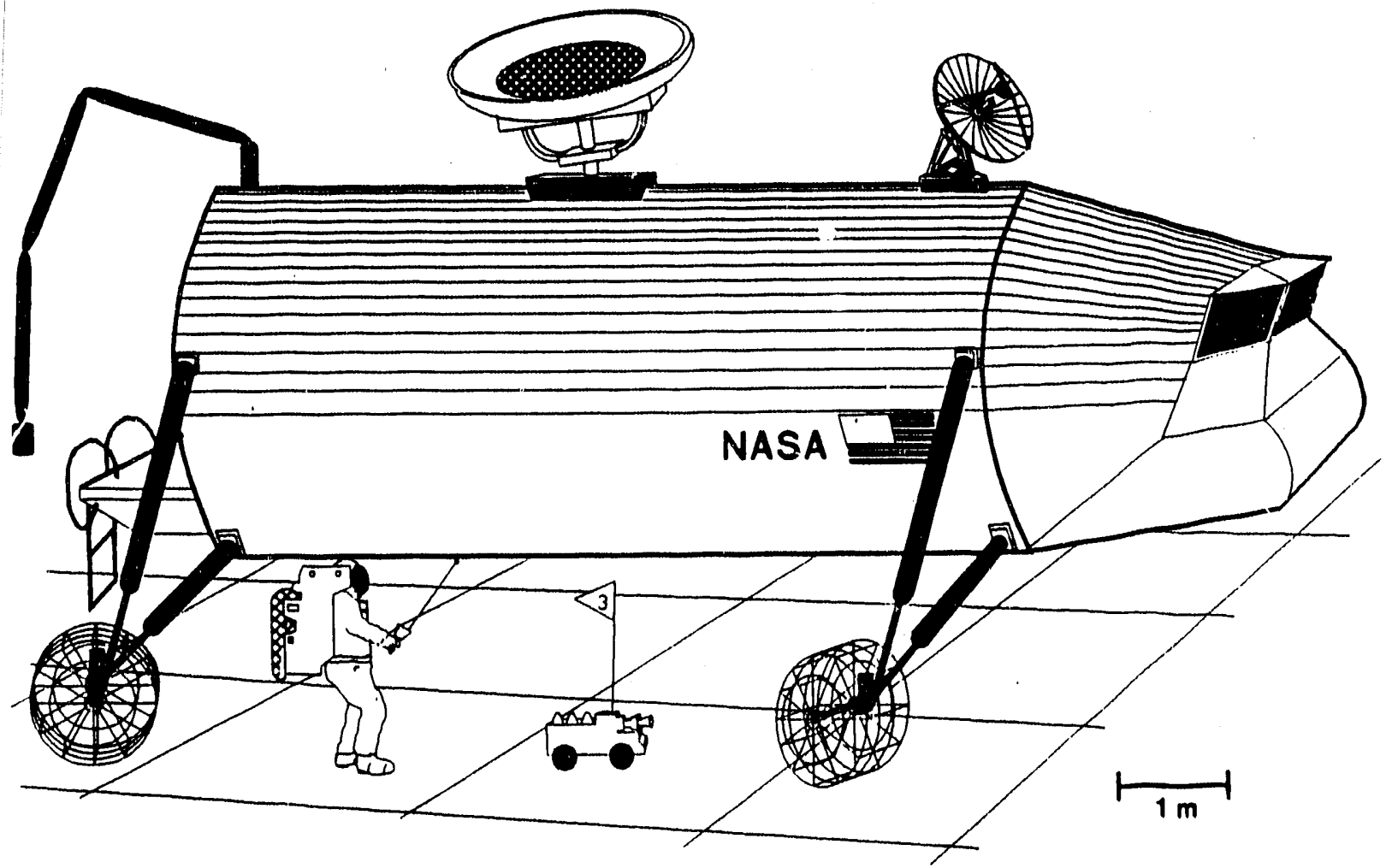

FIGURE 2.1. Laser Beam-Powered Lunar Rover 


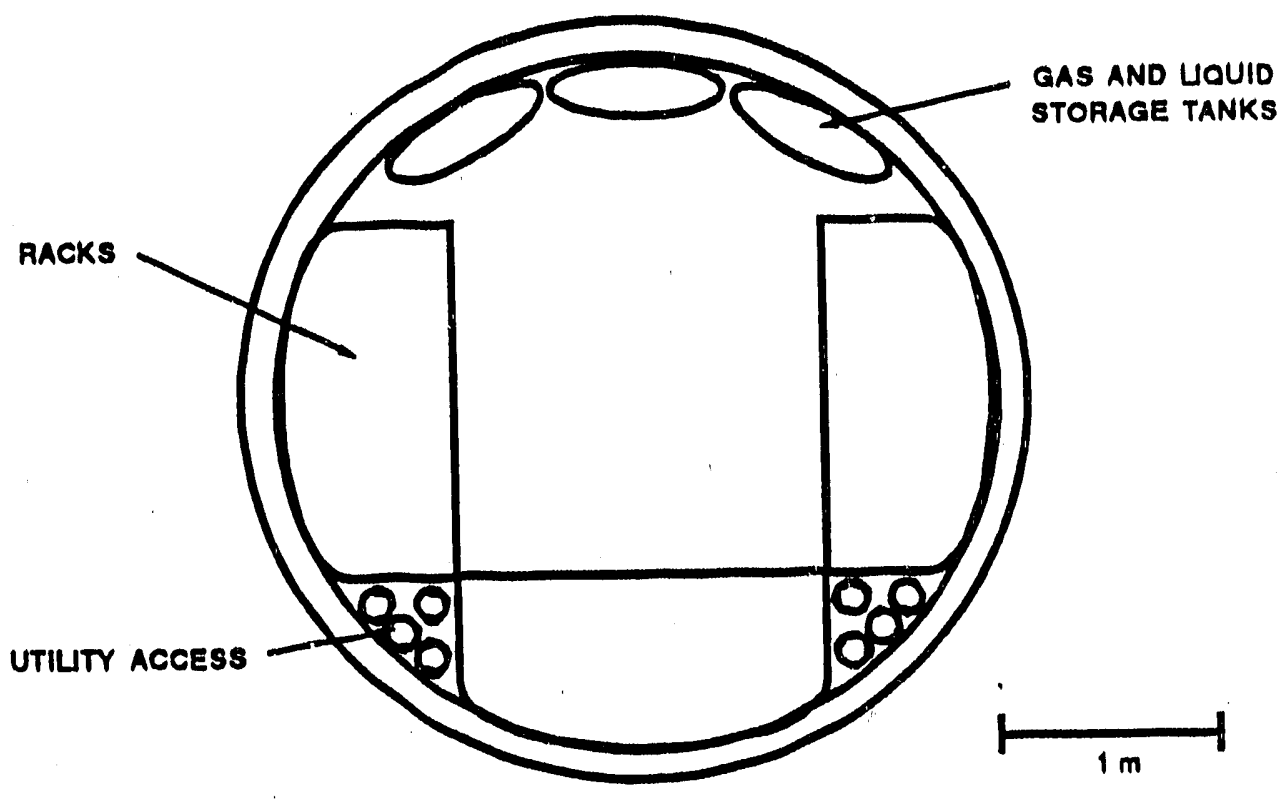

EIGURE 2.2. Internal Cross Section View 


\subsection{POWER SYSTEM DESIGN}

The power for the lunar rover is provided by a photovoltaic receiver which converts laser light to electrical power. The vehicle receives continuous laser power while in motion or at rest. This enables the rover to operate continuously in either mode, thus eliminating limitations on travel distance or placing constraints on mission operation.

\subsection{POWER REOUIREMENTS}

The system design provides an abundance of electrical power. This enables the rover to perform a variety of functions and missions not possible with other rover concepts. A summary of the power system requirements for the various functions of the rover is provided in Table 3.1.

Power for external illumination is included in the drive system power allocation, which would be compensated for by reduced average speed. Only a slight reduction in the average traveling speed would provide significant additional power available for illumination during night operations.

The thermal management power consumption is a function of energy dissipated within the pressurized module. It is assumed that all mission, control, lighting, habitation, housekeeping, servicer recharge, and power system losses will ultimately result is waste heat dissipated into the module. This waste heat must be moved from the habitat module at $300 \mathrm{~K}$ to the radiator

TABLE 3.1. Power Allocation Summary

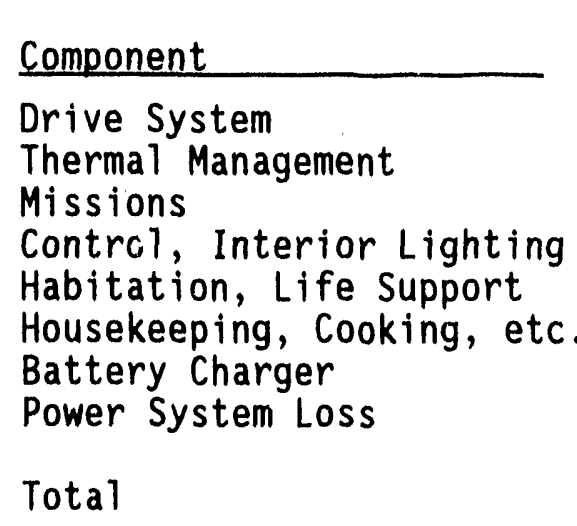

\begin{tabular}{cr}
\multicolumn{2}{c}{ Average Power $(\mathrm{KW})$} \\
\hline Driving & Stopped \\
15.0 & 0.0 \\
5.0 & 10.0 \\
2.0 & 10.0 \\
2.5 & 2.5 \\
2.0 & 2.0 \\
0.0 & 2.0 \\
2.0 & 2.0 \\
1.5 & 1.5 \\
30.0 & 30.0
\end{tabular}


at $400 \mathrm{~K}$. However, power consunied outside the pressurized module, which includes the drive motors and the external lighting, would not have to be removed using this system.

Mission-related hardware, which includes sampling and analysis equipment, will be used primarily when the rover is stationary. However, some power has been allocated for consumption during periods of rover motion to account for possible long-term experiments that cannot be shut down or autonomous functions which may be continuous.

The control functions include communication equipment, somputer systems related to rover operation, rover instrumentation and diagnostic equipment, and internal cabin illumination.

Habitation and life support include all critical functions for conditioning the air, such as ventilation and $\mathrm{CO}_{2}$ scrubbing. Housekeeping includes al1 noncritical functions for living on the rover which may be switched off during periods of mobility. This includes functions such as water treatment and food preparation.

A battery charging system is included for robotic minirovers, as well as any mission-related battery-operated equipment. This power is available continuously to eliminate operational constraints.

The power distribution system is assumed to be $95 \%$ efficient, which is reasonable given the simplicity of the design and the relatively short cable runs required.

\subsection{LASER RECEIVER}

The laser energy transmitted to the surface is converted to electricity by an AlGaAs photovoltaic converter, as shown in Figure 3.1 (De Young et al. 1991). Since the converter is tuned to the laser wavelength, very high conversion efficiencies on the order of $50 \%$ are achieved. A heat rejection system is included to remove waste heat and to maintain the receiver photovoltaics at $320 \mathrm{k}$. 


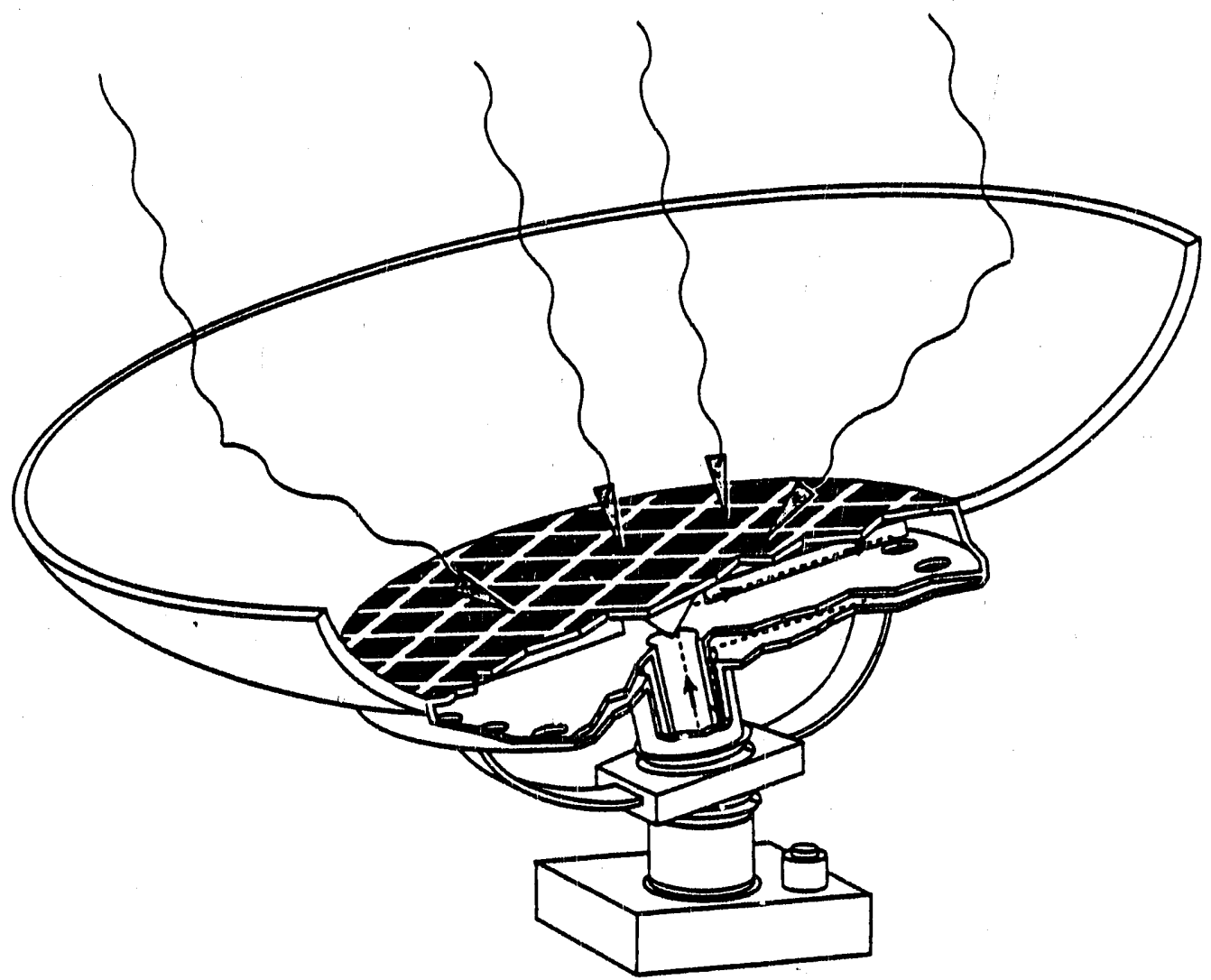

FIGURE 3.1. Laser Receiver Schematic Diagram

The laser receiver mass breakdown is listed in Table 3.2. The laser receiver was scaled using De Young's (1991) design, converting the net electrical output from $15 \mathrm{~kW}$ to $30 \mathrm{~kW}$. Each component of the converter mass is doubled, except the tracking device and the coolant piping. The tracking

IABLE 3.2. Laser Receiver Mass Breakdown

Component

AlGaAs Cells

Active Area Matrix

Laser Concentrator

Tracking System

Thermal Management System Radiator Coolant Piping Compressors

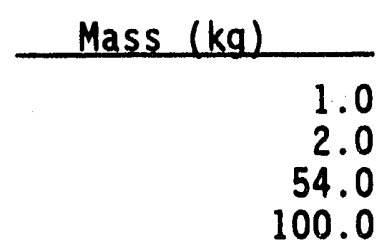

464.0

159.0

120.0

743.0

900.0

Tota! 
device does not scale with power, since it is primarily structure and control systems associated with receiver orientation. The coolant piping mass increases by a factor of $\sqrt{2}$, which represents doubling the effective piping area. The receiver size is relatively, unaffected by increasing power, since the reflector dish surrounding the active area is primarily a function of beam jitter and diffusion, which depends on the separation distance, wavelength, and pointing accuracy. The laser receiver is about $2 \mathrm{~m}$ in diameter.

\subsection{ENERGY STORAGE}

Although the laser system is sized to provide average power for both stationary and mobile modes of operation, brief periods of either above or below average power will occur regularly as equipment is switched on and off. These load variations will be compensated for by onboard energy storage. This energy storage can also be used for emergency conditions when there is an interruption in receiving laser energy or a system failure on the rover that precludes normal operatior. This emergency stand-by power will be adequate to maintain the rover in a "keep ai ive" mode until rescue or to provide power to perform limited maneuvering.

Two fuel cells in parallel will provide energy storage with an overall capacity of $30 \mathrm{~kW}$ and $50 \mathrm{kWh}$. Near-term fuel cell technology has specific power of $7 \mathrm{~kW} / \mathrm{kg}$ and energy storage density of $225 \mathrm{Wh} / \mathrm{kg}$. The onboard fuel cells have a total mass of $300 \mathrm{~kg}$.

If $30 \mathrm{kWh}$ is dedicated as emergency stand-by energy, with the remaining stored energy available for routine load variations, the life support system could operate at full capacity for a minimum of 15 hours.

\subsection{DISTRIBUTION SYSTEM DESIGN}

Figure 3.2 is a one-1ine diagram of the rover power system. The system incorporates the concept of a dual bus, which minimizes the effect of a single-point power system failure. Each bus occupies one rack on each side of the vehicle and provides power to racks on the same side of the vehicle. Thus, any redundant critical hardware, such as life support equipment, are 


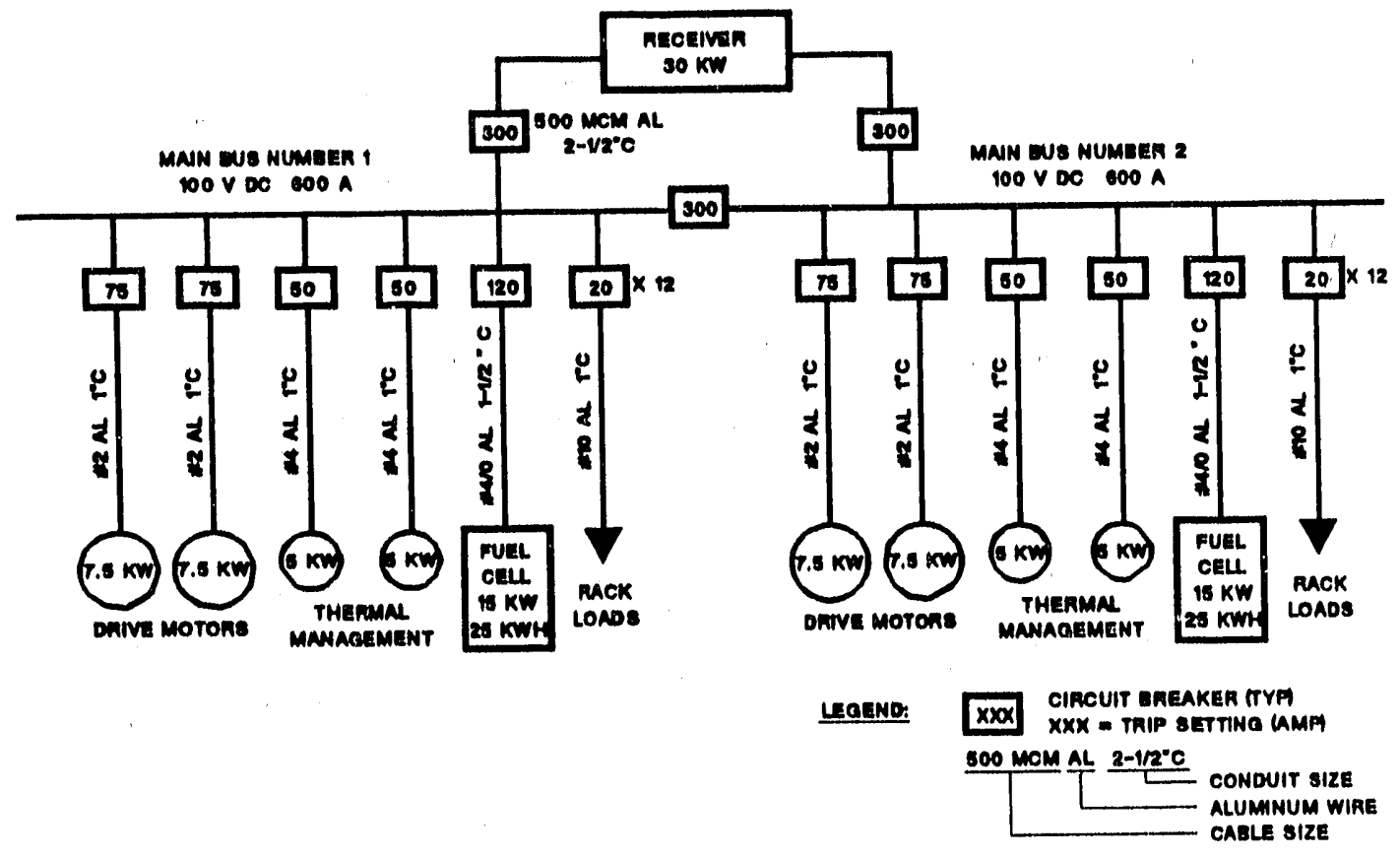

FIGURE 3.2. Power System One-Line Diagram

installed in racks on different sides of the vehicle. The fuel cells are located in racks adjacent to each bus.

A mass breakdown of the power system components is provided in Table 3.3. Somewhat contrary to traditional aerospace design, which must sometimes trade between mass savings and efficiency improvement, reduction in mass can be made at the expense of efficiency due to the power-rich environment. Smaller lightweight cables can be used, which result in higher power system losses. This power system has a design efficiency of $95 \%$. 
TABLE 3.3. Mass Breakdown of Power Distribution System

Component

Main Bus (2)

Cable (Aluminum THW) $500 \mathrm{MCM}$

\#4/0

$\# 2$

\#4

$\# 10$

Conduit (Polyvinyl Chloride, Schedule 40) $2-1 / 2$ in. $1-1 / 2$ in. 1 in.

Circuit Protection, Switches, Misc.

Total

Source: Means 1990
$\operatorname{Mass}(\mathrm{kg})$

$15.8 \mathrm{~m}$

1.2

36.6

2.4

131.7

$7.9 \mathrm{~m}$

0.6

36.0
30

73

24

150 


\subsection{MECHANICAL DRIVE SYSTEM DESIGN}

The lunar rover drive-train design is lightweight and uses current technology for electric motors and heat rejection. This drive system is we11matched to the continuous, relatively large amount of power available from power beaming. As a result, the rover has extended range, increased speed, and enhanced maneuverability.

\subsection{LUNAR SOIL AND TERRAIN FEATURES}

The lunar regolith (surface debris layer corresponding to terrestrial soi1) consists of particles ranging from fine dust to rocks (Levinson and Taylor 1971; Mason and Melson 1970). This regolith was formed by meteorite impacts that resulted in shocked fragments of rocks, minerals, and glass spherules (Smith and West 1982, p. 3-13). The bulk of the regolith is made up of fine particles that are porous and weakly coherent at the surface but become more compacted with depth. Typically, a thin dusty surface layer about $1 / 4-\mathrm{cm}$ thick covers a dark gray caked zone, below which there is a 5- to $15-\mathrm{cm}$ thick slightly cohesive sandy to silty material (Levinson and Taylor 1971, p. 82). Underlying these zones is a layer that exhibits an increase in firmness and resistance to penetration. The thickness of the regolith is quite variable with location, but is estimated to be between 3 and $20+\mathrm{m}$ (Smith and West 1982, p. 3-13; Williams and Jadwick 1980, p. 60). The depth of the material appears to be enough to preclude penetration of any conceivable rover wheel through the regolith. Note, however, that the data base for the above values is rather limited (horizontally and vertically) in terms of actual exploration. For example, astronauts were able to obtain core samples only about $60 \mathrm{~cm}$ deep (Williams and Jadwick 1980, p. 61).

of main interest here is that mechanically lunar soils behave similarly to terrestrial soils of comparable particle size, even though composition may be different (Smith and West 1982, p. 3-24). In particular, both astronaut footprints and lunar rover tracks penetrated the regolith to depths ranging between 0 and $15 \mathrm{~cm}$ (Williams and Jadwick 1980, pp. 61 and 62). The majority of lunar slopes have angles <20 degrees (Smith and West 1982, pp. 3-18 and 3-19), so the 30 -degree rover climbing 1 imit will restrict travel very little. 


\subsection{ROVER PROPULSION REOUIREMENTS}

The rover propulsion power requirements include a combination of acceleration, climbing, and horizontal motion in soft soil. Each of these are described separately below, then integrated into the overall requirements.

\subsubsection{Acceleration}

Since acceleration is defined by Newton's first law ( $F=m a)$, in order for the $8000-\mathrm{kg}$ rover to reach its top speed of $10 \mathrm{~km} / \mathrm{hr}$ in $5 \mathrm{~s}, 12.3 \mathrm{~kW}$ of power is required, at near-maximum velocity.

\subsubsection{Climbing}

For the lunar gravity, which is one-sixth that on Earth, $18.2 \mathrm{~kW}$ is required to maintain the $10-\mathrm{km} / \mathrm{hr}$ top speed while climbing a 30 -degree slope with firm soil. At lower speed on the same slope, power would drop proportionately.

\subsubsection{Horizontal Motion on Regolith}

The rolling resistance of a wheel is a function of wheel and ground deformation. Given the soft lunar regolith, it appears reasonable to ignore wheel deformatinn and use the standard equation to calculate power requirements. In the equation $P=W b / r$ (English units), $P=$ force, $W=$ vehicle weight, $b=$ coefficient of rolling resistance, which is a dimension somewhat less than one-half the maximum distance of the wheel segment penetrating into the soil, and $r=$ wheel radius (Beer and Johnston 1962, p. 300). Given a $1.2-m$ diameter wheel that experiences a b of $12.5 \mathrm{~cm}$ (typical of soft soil), the power required to maintain forward motion is $7.54 \mathrm{~kW}$, which is the force multiplied by the vehicle speed. This implies that the wheel penetrates into the regolith to a depth $\geq 1.7 \mathrm{~cm}$.

Assuming that the wheel will penetrate the full $15 \mathrm{~cm}$ experienced during the Apollo 16 rover missions, then $b$ is approximately tripled and the power requirement rises accordingly. Alternately, given constant power, one could elect to reduce speed from 10 to $3.3 \mathrm{~km} / \mathrm{hr}$ over the softer regolith. 


\subsubsection{Propulsion Power Requirements Summary}

The previously calculated power requirements are summarized in Table 4.1. The third column shows an increased requirement after incorporating an assumed $75 \%$ overall drive-train efficiency, which is a conservative as sumption.

Thus it appears that if an average power of $15 \mathrm{~kW}$ were made availabie to the rover drive via power beaming, the assumed acceleration and steady horizontal speed criteria could be readily met, or nearly met. climbing would have to be done at $<10 \mathrm{~km} / \mathrm{hr}$, and horizontal travel in soft regolith would also be at slower speeds. Alternately, additional power could be produced from an onboard energy storage system. A specific mission profile would be required to calculate the tradeoffs necessary for mission optimization.

\subsection{DRIVE-TRAIN DESIGN}

The following sections describe the components of the drive train.

\subsubsection{Electric Motors}

Recent developments in high-efficiency, low-mass electric motors can be used to advantage in a rover vehicle. For example, a journal articie (Aerospace America 1988) describes a research motor that produces $10.5 \mathrm{kH}$ at $20,000 \mathrm{rpm}$ and weighs $14 \mathrm{~kg}$. Similar, somewhat smaller motors are currentiy available from Unique Mobility (1991). The DR086x motor produces $7.5 \mathrm{~kW}$ at $10,000 \mathrm{rpm}$, and weighs $4.3 \mathrm{~kg}$; a somewhat more powerful and heavier motor,

IABLE 4.1. Propulsion Power Requirements

Mode

Acceleration

Climbing

Steady speed/horizontal

Maximum(a)

\begin{tabular}{cc} 
Power Requirements $(\mathrm{kW})$ \\
\hline $100 \%$ & $75 \%$ \\
Efficiency & Efficiency
\end{tabular}

12.3

18.2

7.5

38.0
16.4

24.3

10.1

50.8

(a) Implies acceleration on a 30-degree slope covered with soft soil, and speed near maximum. 
the DR127x, produces $15 \mathrm{~kW}$ at $8,000 \mathrm{rpm}$, and weighs $6.7 \mathrm{~kg}$. It w111 be assumed here that four of the smaller motors will be adequate for rover propulsion. These motors, plus associated gear reduction, braking, and heat rejection systems, are mounted in complete units, with one assembly per wheel. Motor controllers are also one per wheel, but will reside within the cabin and reject heat into it. Other relevant motor characteristics are summarized in Table 4.2.

\subsubsection{Gear Reduction}

The $1.22-\mathrm{m}$ diameter wheels turn at about $43 \mathrm{rpm}$ at a maximum speed of $10 \mathrm{~km} / \mathrm{hr}$. A double-reduction fixed gear of about 250:1 should be readily achievable to match the motor to the desired speed range.

\subsubsection{Braking}

The Unique Mobility motors can be operated as generators (personal communication with S. Meyer 1991). Typically, this provides $30 \%$ energy recovery over a complete duty cycle on Earth. A disc brake system similar to one that was proposed for a rover vehicle (Price et al. 1990) will be employed here also.

\subsubsection{Heat Rejection}

Surface temperatures on the moon present extremes. For example, at the Apo110 17 site, temperatures ranged from $384 \mathrm{~K}$ during the day to $102 \mathrm{~K}$ just before sunrise (Smith and West 1982, p. 3-26). The moon reflects about $7 \%$ of

\section{TABLE 4.2. Electric Motor Specifications}

\section{Characteristic}

Voltage

Dimensions

Efficiency (over $70 \%$ of speed range) Operating Temperature (continuous) Vacuum Operation Over-Torque Rating (short term)

$$
\begin{array}{r}
\text { Amount } \\
50 \text { to } 100 \mathrm{DC} \\
\text { (with higher } \\
\text { voltage preferred) } \\
122 \mathrm{~mm} \text { diameter } \\
\times 133 \mathrm{~mm} \text { long } \\
90 \% \\
422 \mathrm{~K} \\
\text { Not a problem } \\
\text { Up to } 300 \%
\end{array}
$$

Source: Clark et a1. 1991 
incident 1ight, with the brightest areas exceeding the darkest by 3.5:1 (Smith and West 1982, p. 3-26). These conditions create a challenging temperaturecontrol problem.

At full power and with an efficiency of $90 \%, 3.33 \mathrm{~kW}$ of heat needs to be rejected from the electric drive motors (transmission efficiency should be high enough that little heat will be generated there). At $422 \mathrm{~K}$ motoroperating temperature, $1.83 \mathrm{~m}^{2}$ of radiator surface would be required to reject this amount of heat to space. Rejection of heat to the lunar surface at $384 \mathrm{~K}$ would require $5.84 \mathrm{~m}^{2}$, so this is also a feasible option although a difficult one to implement given the soil's albedo and temperature variabilities. It. will be assumed here that a shrouded heat pipe panel radiator that views space only, with a view factor of about 0.2 , will be mounted on the rover body. Thus about $10 \mathrm{~m}^{2}$ of (projected or actual) radiator area will be required in this design.

The radiator will consist of metal/ceramic fabric heat pipes using water as the working fluid and having a specific mass of $3 \mathrm{~kg} / \mathrm{m}^{2}$ (Antoniak et al. 1991). The flexible heat pipes would expand and contract in length ("party favor") with the heat load to match motor needs. Coolant loops at the motors and heat exchangers at the radiator panels will serve to transfer the heat from the motors to the radiators. The heat-transfer medium in the loops could be pressurized water, or an oil-type organic fluid at lower pressure than the water would require. Test results have shown that metal/ceramic fabric heat pipes can be effectively started while frozen (Antoniak et al. 1991).

\subsubsection{Control}

A full range of variable speed control is available via the CR10-100 Unique Mobility controller (Unique Mobility 1991). This controller weighs about $2.7 \mathrm{~kg}$ (personal communication with $\mathrm{S}$. Meyer) and attains efficiency up to $97 \%$. It also provides energy recovery by means of regenerative braking.

\subsection{DRIVE-TRAIN MASS SUMMARY}

The masses of the drive-train components, as well as total mass, are given in Table 4.3. 
TABLE 4.3. Drive-Train Mass Summary

\begin{tabular}{|c|c|c|c|}
\hline \multirow[b]{2}{*}{ Component } & \multirow[b]{2}{*}{ Number } & \multicolumn{2}{|c|}{ Mass $(\mathrm{kg})$} \\
\hline & & Unit & Total \\
\hline $\begin{array}{l}\text { DR086x Motors } \\
\text { Gear Reduction } \\
\text { Control } \\
\text { Brakes } \\
\text { Radiator } \\
\text { Heat Exchangers } \\
\text { Miscellaneous }\end{array}$ & $\begin{array}{l}4 \\
4 \\
4 \\
4 \\
1 \\
4\end{array}$ & $\begin{array}{c}4.3 \\
5.0 \\
2.7 \\
5.0 \\
\left(3 \mathrm{~kg} / \mathrm{m}^{2}\right) \\
5.0\end{array}$ & $\begin{array}{l}17.2 \\
20.0 \\
10.8 \\
20.0 \\
30.0 \\
20.0 \\
50.0\end{array}$ \\
\hline Wheels and Suspension & 4 & 50.0 & 200.0 \\
\hline Complete Drive System & & & 368.0 \\
\hline
\end{tabular}




\subsection{HABITAT AND LIFE SUPPORT SYSTEM}

The vehicle will provide shirt-sleeve accommodations for as many as 4 crew members on 30-day lunar exploration missions. In each of the following sections the requirements for the designated Life Support Subsystem (LSS) are first established, then followed by a discussion of the required subsystems.

\subsection{GENERAL}

The vehicle LSS design is open, using regenerable subsystems based on state-of-the-art physicochemical technologies. This means there will be fewer expendables and the capability to recharge the vehicle's subsystems for repeated exploration trips. The level of operation of the various subsystems has been set to meet the technology road map and milestones of the Exploration Technology Program in NASA's Office of Aeronautics, Exploration and Technology. The LSS technologies were also chosen to be as compatible as possible with those foreseen for the Initial Lunar Outpost (ILO) in its emplacement and consolidation phases.

There is not unanimous agreement on the volume and weight requirements for food, air, and materials necessary to support crew members on space missions. One can estimate as high as $32 \mathrm{~kg} /$ day of supplies to maintain a person in a totally open LSS, which would require 1 metric ton of supplies/personmonth for the rover. Most of the estimated weight is water for personal hygiene, washing clothes, and flushing. The weight requirement can be reduced to about one-third of this figure if less water is used.

\subsection{ATMOSPHERE}

Vehicle atmosphere will be $20 \% \mathrm{O}_{2}$ and $80 \% \mathrm{~N}$ at $14.7 \mathrm{psi}$, with minimal $\mathrm{CO}_{2}$ and trace contaminants. This will require $0.8 \mathrm{~kg} 0_{2}$ and $0.7 \mathrm{~kg} \mathrm{~N} /$ person/ day. For a 30-day, 4-person crew mission, the weight requirements are $100 \mathrm{~kg} \mathrm{O}_{2}$ and $80 \mathrm{~kg} \mathrm{~N}$. This does not include air lost in airlock operations or spare capacity.

A two-bed molecular sieve will be used for air scrubbing for $\mathrm{CO}_{2}$ removal, replacing the four-bed molecular sieve developed for SSF. This will eliminate 
two desiccant beds upstream of the two $\mathrm{CO}_{2}$ beds in that model with concomitant weight and space savings. The $\mathrm{CO}_{2}$ can be vented or reduced.

$\mathrm{CO}_{2}$ can be reduced using the well-known Sabatier or Bosch processes. The Sabatier process has significant mass, power, and volume advantages over the Bosch process, but produces methane which must be vented or otherwise processed. The SSF will use a Bosch process which produces solid, elemental carbon. This vehicle and the lunar base could most profitably use the Sabatier process if the methane could be successfully used as a fuel or otherwise reduced to its carbon and hydrogen components.

\subsection{WATER}

Since water constitutes over $90 \%$ of the consumable loss of a LSS, it is a high priority to reduce this loss. SSF estimates are as high as $22 \mathrm{~kg}$ of water/person/day for total us 3 . Estimates of water requirements vary widely across sources, mostly due to uses of water for other than drinking. Most agree that each crew member will need 2 to $5 \mathrm{~kg}$ of drinking water daily depending on their activity leve1. For a 30-day, 4-person crew mission, weight requirements for drinking water are from 240 to $600 \mathrm{~kg}$.

The vehicle will carry two kinds of water: potable water used for drinking and food preparation, and laboratory water for onboard analytical use. The potable water loop will be partially closed by recovering condensate water (humidity) from the atmosphere and purifying it by multifiltration to remove dissolved organic vapors and metal ions. The laboratory water will probably have to be deionized if it is used in chemical tests. Lab residues will be stored onboard for later disposal or recovery at the lunar base.

Onboard the vehicle, no water will be used for bathing or washing clothes or dishes. Tissue wipes will be wsed for bathing. Potable water will be used to brush teeth with residues stored with other wet residues from food preparation.

The crew will wear disposable undergarments and outer clothes that will be changed at regular intervals. Undergarments, and perhaps some other clothes, can be made of degradable materials which can be combined and eventually recycled with other solid wastes after the mission is complete. 
Food storage, preparation, and serving materials will be combined in degradable packaging which will be compacted and returned to the lunar base for recycling with other solid waste. (Food packages create about half of the solid trash weight produced daily on the Space Shuttle.)

\subsection{FOOD}

The reviewed literature shows strong agreement for food requirements for space crews, ranging from 1.0 to $1.5 \mathrm{~kg} /$ person/day. For a 30-day, 4-person crew mission, this would be about $150 \mathrm{~kg}$ of food. Food volume depends on packaging and food type, but $0.015 \mathrm{~m}^{3} /$ person/day appears adequate for solid foods. Total food volume for storage would then be about $1.8 \mathrm{~m}^{3}$.

Food could be all dehydrated, or mixed dehydrated and frozen depending on the thermal management subsystem of the vehicle. Food will be prepared by reconstituting with water and heating via microwave and/or solar cook unit.

\subsection{WASTE}

A crew member produces $0.113 \mathrm{~kg}$ of water weight and $0.024 \mathrm{~kg}$ of solid weight in feces every day and 0.7 to $0.9 \mathrm{~kg}$ of urine. This translates into $16 \mathrm{~kg}$ of fecal material and up to $108 \mathrm{~kg}$ of urine for a crew of 4 on a 30-day mission. These wastes should be kept separate and either treated or stored for treatment in a manner compatible with waste recovery for the lunar base.

The minimurn waste treatment scheduled for the ILO is recovery of water from urine and from solid wastes, both for nonpotable uses. SSF will recover water from urine for noningestive uses only.

Solid waste recovery is the least well developed of LSS technologies, and development of a long-term system for water recovery from urine for the SSF has been shown to be extremely difficult due to the corrosive nature of urine. This vehicle is therefore planned to store urine and fecal materials onboard in separate storage tanks for transfer and subsequent recycling treatment. Fecal materials can be collected and stored in degradable 'baggies,' which will save use of water for flushing, while urine can be collected directly into a special holding tank as aboard the Space Shuttle. 


\subsection{TRASH}

Current Space Shuttle experience indicates that a space crew generates 1.0 to $1.1 \mathrm{~kg}$ of trash/person/day. The (noncompacted) volume formation rate is approximately $0.015 \mathrm{~m}^{3} /$ person/day. Food containers account for about half of this by weight $(0.47 \mathrm{~kg} /$ person/day) with the remainder being mostly paper and biomedical wastes $(0.13 \mathrm{~kg}$ each), leftover food $(0.09 \mathrm{~kg})$, plastic bags $(0.06 \mathrm{~kg})$, and tape, aluminum cans, and miscellaneous $(0.10 \mathrm{~kg})$.

Because tape is used mainly for securing people in weightless conditions, biomedical wastes will probably be minimal; and aluminum cans will likely be replaced by different packaging for lunar missions, thus trash generation aboard this vehicle should be kept below the nominal $1 \mathrm{~kg}$ and $0.015 \mathrm{~m}^{3} /$ person/ day formation rate. For a 4-crew member, 30-day mission this amounts to $120 \mathrm{~kg}$ of trash by weight and $1.8 \mathrm{~m}^{3}$ by volume that could be compacted and stored aboard the vehicle for later treatment or disposal at the lunar base.

\subsection{RADIATION ENVIRONMENT AND SHIELDING}

The two sources of 1 ife-threatening radiation are Galactic Cosmic Rays (GCRs) and Solar Flares (often called Solar Proton Events or SPE). GCRs are high-energy heavy and light ions. Solar flares are high-energy proton bursts. GCR exposure on the lunar surface is a constant 25 to $35 \mathrm{mrads} /$ day. Solar flares are much more dangerous and variable, occurring in an 11-yr cycle. Within each cycle there are 1 to 2 major events of $\sim 5000$ rads (considered lethal), 2 to 5 moderate events of 500 to 1000 rads, and 20 to 30 minor events of 50 to 100 rads each. Current radiation limits for astronauts are set at 200 rems for a cumulative lifetime career, $50 \mathrm{rems} / \mathrm{yr}$ and $25 \mathrm{rems} / \mathrm{mo}$. A rem is a biological radiation dose which includes a measure of relative biological effectiveness for specific radiation types.

To convert rads to rems, multiply the dose in rads by the relative biological effectiveness of the type of radiation exposure. These multipliers range from 1 for direct $X$ and gamma rays to 1 to 10 for solar flare protons from $100 \mathrm{MeV}$ to $0.1 \mathrm{MeV}$, and 15 to 20 for alpha particles from 5 to $1 \mathrm{MeV}$.

Prediction of solar flare events is notoriously poor, making protection from these events the prime consideration of vehicle shielding. The vehicle 
should be at least as protective as an EVA suit, which would result in an unacceptable exposure of $130 \mathrm{rems} / \mathrm{mo}$ to the arms and legs of an explorer. More reasonably, the rover vehicle should be able to shield its occupants to a maximum $25 \mathrm{rem} / \mathrm{mo}$ exposure under solar minimum situations. Some ancillary shielding strategy will be necessäry (hiding behind protective terrain, deployable shielding, or an internal flare shelter) to protect the crew from major SPEs up to 500 rads.

There appears to be agreement that 1 to $3 \mathrm{~m}$ of loosely packed lunar regolith would be sufficient to shield a lunar base.

The approximate shielding for a $50 \mathrm{rem} / \mathrm{yr}$ dose 1 imit from GCR would require $2.3-\mathrm{cm}$ thickness of $A 1$ at a density of $60 \mathrm{~kg} / \mathrm{m}^{2}$. The dose equivalent curves for GCR and SPEs show a rapid drop with increasing thickness of $A 1$ up to $10 \mathrm{~cm}$. The curves break noticeably after this point, indicating decreasing marginal benefits with increasing thickness.

Keeping weight of the vehicle down while providing adequate radiation protection for a 30-day mission will be problematic. Water may be used as shielding $\left(3.6 \mathrm{cn} \mathrm{H}_{2} \mathrm{O}=2.3 \mathrm{~cm}\right.$ of $\mathrm{Al}$ ) but it is only as effective as methane, which has less than half its density. Methane would be produced as part of $\mathrm{CO}_{2}$ reduction under the Sabatier process, and would make excellent shielding if it could be safely stored. Using water as shielding implies that it should also be recirculated for nonpotable uses such as cleaning, but this adds to the mass and LSS complexity of the vehicle.

The rover design uses a combination of water, methane, and waste water storage in the overhead bulkhead to augment $1.6 \mathrm{~cm}$ of aluminum shielding.

\subsection{INTERIOR VO' IMME AND SPATIAL ARRANGEMENTS}

Many studies over the past 30 years have looked at volume requirements for crews of space vehicles (see Wise 1985, for a review). They are in agreement that proficiency of the crew is directly related to the free volume available, and that when space is limited, normal housekeeping and hygienic chores consume large portions of the working day. 


\subsubsection{Background}

Davenport et al. (1963) propose an approximate minimum of $3.1 \mathrm{~m}^{3} /$ person for a 4-person, 30-day space mission.

The Lunex simulator used $4.4 \mathrm{~m}^{3}$ free volume for a 2-man, 14-day mission, which included an airlock space which was rarely used. This would be in keeping with the guidelines set by Davenport et al. (1963). But this study also noted severe problems with housekeeping and hygiene as the crew simply tried to stay out of each other's way and get things done. The small volume here was also partially due to a lower overhead height of just $1.7 \mathrm{~m}$.

Wise (1985) found, after an extensive review of all available literature, that "It's not how large you make it, but how you make it large." Interior free volumes can be kept at or below $4.25 \mathrm{~m}^{3} /$ person for up to 30 -day missions as long as the available space and interior layouts are designed to meet the crew's functional needs, and certain treatments are employed to make the available volume appear as spacious as possible. It is relatively easy, for example, to make a space appear up to $25 \%$ larger than it actually is simply by using an angled bulkhead.

\subsubsection{Basic Design}

The lunar rover is designed to make functional use of airlock space and incorporates a highly functional interior design. The interior free volume is $30 \mathrm{~m}^{3}$. The design uses a "three-box" concept that includes 'cockpit' (cab), 'lab/work space,' and 'airlock' areas in sequence from fore to aft.

\section{8 .3 Cockpit (Cab)}

The cockpit is sized to fit all four crew members in $2 \times 2$ supportive seats while driving, as the ride will be rough. An EVA-suited crew member. will be able to occupy the driver's station. Each fore-aft pair of seats are convertible to a sleep berth so that two crew members can sleep in the cockpit and two more in the lab space via "jungle hammocks" suspended from the overhead. The four seats also allow the cab to be reconfigured as an impromptu wardroom, probably through addition of a lightweight folding round table that would fit between the seats. This could be a smaller version of the one designed at NASA-ARC for the SSF. The cab would be the preferred 
place to eat and relax because it is the only place that would allow a window view out from the vehicle.

Thinking of the cab as a 'four-workstation' space suggests that approximately 0.7 to $0.9 \mathrm{~m}^{3}$ minimum free volume should be allocated per crew member. This would be in keeping with using the cab as a minimum habitable volume for four crew members. Assuming two space suits carried aboard the rover, the cab should also allow two suited crew members to operate within it in an emergency. Each suited crew member requires approximately $1.5 \mathrm{~m}^{3}$ to operate controls. Thus minimal cab free volume appears to be resolving around $3.25 \mathrm{~m}^{3}$. For comparison, a current large American automobile allots about $1.5 \mathrm{~m}^{3}$ each to front and rear passenger spaces.

The cab may be a separately shaped volume, as in the Boeing rover study, or incorporated into the same cylinder as the lab space. But the latter wastes space because the 3-m interior width is not needed for driving, and a $c a b$ does not need to have full standing height throughout. A cab interior free width on the order of 1.5 to $1.8 \mathrm{~m}$ is more reasonable as this would allow two EVA-suited crew members to operate side by side. The design tapers the cylinder of the lab to form the cab. Further shaping of the cab requires consideration of whether operable probes and manipulators will be added to its capabilities.

Depth of the cab's free volume aft of the driving console should be at least $2 \mathrm{~m}$ to allow the four crew members to gather around a center deployable table approximately $100 \mathrm{~cm}$ in diameter, and for conversion of fore and aft seats to sleep berths. A curved cab overhead proceeds from overhead console height over the driver to the full $2 \mathrm{~m}$ interior height toward the rear of the cab. This results in a full cab free volume of approximately $4.0 \mathrm{~m}^{3}$, with an overall length of $2.5 \mathrm{~m}$.

\subsubsection{Lab Space}

The '1ab/work space' would be furnished with international racks as used aboard the SSF. International SSF racks are $156 \mathrm{~cm}$ high, (189 $\mathrm{cm}$ with mounts) $60 \mathrm{~cm}$ deep (76 cm with frame), and can be configured in varying widths (use approximately $1 \mathrm{~m}$ wide for planning purposes). For comparison, U.S. SSF racks 
are $203 \mathrm{~cm} \mathrm{high,} 90 \mathrm{~cm}$ deep, and $107 \mathrm{~cm}$ wide. Both U.S. and international racks can be subdivided into half-width segments.

This mandates a minimum interior height of approximately $2 \mathrm{~m}$. This height would also accommodate the tallest crew members while providing room for an overhead bar that would assist crew movement through the interior. Studies on movement under simulated one-sixth lunar gravity suggest such an aid is appropriate.

For safety, EVA suit access throughout the vehicle must be allowed. A 95th percentile male in an EVA suit requires $192-\mathrm{cm}$ height, $85-\mathrm{m}$ width, and $69-\mathrm{cm}$ depth. Note that this is for the current soft suit. A more likely hard suit for surface operations might require more in width and depth.

There is now a tradeoff to be made between designing a vehicle with a single- or a double-loaded central lab space (i.e., racks on one or both sides of the vehicle). For balance purposes, double-loaded racks are preferred. For a vehicle with a double-loaded central corridor using international racks, the minimum interior volume dimensions would be $200 \mathrm{~cm} \mathrm{high,} 238 \mathrm{~cm}$ wide, and long enough to accommodate whatever number of racks is required.

Adding shielding and hull easily puts the vehicle at $3 \mathrm{~m}$ wide. The Boeing lunar rover uses a horizontal cylinder for its airlock, which is $3.4 \mathrm{~m}$ in width (Griffin 1991). Accordingly a 3.0 to $3.4-\mathrm{m}$ wide cylinder for the central lab space appears feasible.

The length of the $1 \mathrm{ab}$ space cylinder depends on the number and types of rack instruments and equipment. A minimum would seem to be five racks (approximately $500 \mathrm{~cm}$ ) on a side, for an overall 1ab length of about $5 \mathrm{~m}$.

\subsubsection{Airlock}

Standard airlock design houses the EVA suits within it and allows enough room to doff/don suits. However, a suitport concept explored at NASA-ARC for SSF has much to recommend it for adaptation to a rover (Cohen 1985).

The suitport concept places AX-5 type hardsuits outside the pressurized interior volume, attached directly to life support charging and checkout systems. Entry is through a backpack door on the suit that locks tight against the pressurized bulkhead. The suit itself can be shielded from the external 
environment by a form-fitted cover that closes over it. This suitport has the highest volumetric efficiency of any type tested so far, meaning minimal loss of interior atmosphere during pumpdown for entry and exit. It also prevents contamination of the interior by lunar dust that will adhere to the suits. These should be major considerations for repeated lunar surface EVAs from a rover.

The two suitports proposed for this rover could be housed at the aft end of the lab space. The area adjacent to the suitport could house a receiving station for surface materials on one side and an enclosed hygiene facility on the other. This would occupy one rack width each, with another rack width open behind the suitports, adding another $200 \mathrm{~cm}$ to the $1 \mathrm{ab}$ cylinder length. Total exterior lab cylinder length would now be approximately $7.5 \mathrm{~m}$.

Within the 2.4-m interior diameter of the lab cylinder, two suitports could be positioned side by side, leading to an exterior 'porch' on the aft of the rover.

\subsubsection{Summary}

The entire rover is $10 \mathrm{~m}$ long, making it suitable for launch in the Space Shuttle cargo bay. The rover could even be designed as an independent 'cab plus lab trailer' vehicle, and kept to under $14 \mathrm{~m}$, the limit for the Space Shuttle. This would be in keeping with the Rover First concept, which visualizes a rover taking the place of the ILO. There could be detachable 'trailer' cylinders of different kinds that would eventually be linked together in the first permanent lunar base. 


\subsection{CABIN HEAT REJECTION SYSTEM}

Power-beaming is a mission-enabling technology for the lunar rover. It will provide high levels of continuous power, thereby expanding the list of potential mission objectives. However, the energy beamed to the rover must ultimately be dissipated as heat.

\subsection{DAYTIME OPERATION}

Waste heat rejection in the lunar environment introduces some unique challeriges. The heat must be rejected through radiation to space and to/from the lunar surface. Depending on the time of 'day,' the location on the lunar surface, and the design heat rejection temperature, the lunar surface may be a net heat source or a net heat sink. The sink temperature for radiation can be relatively high because of the high daytime lunar surface temperatures, up to $384 \mathrm{~K}$ (Smith and West 1982). Ewart and Clark (1991) calculate an available daytime he " $i$ sink temperature of $322 \mathrm{~K}$ for a vertical unshaded radiator at the lunar equator.

A simple heat balance allows calculation of the required radiator temperature as a function of heat load and lunar and radiator physical properties

$$
T_{r \theta j}=\left(\frac{Q_{r \theta j}+F_{s} \alpha_{R} \sigma A_{R} T_{s}^{4}+F_{m} \epsilon_{m} \alpha_{R} \sigma A_{R} T_{m}^{4}}{A_{R} \epsilon_{R} \sigma}\right)^{0.25}
$$

$\begin{array}{ll}\text { where } & T_{r e f} \text { is the radiator operating temperature } \\ Q_{r e j} & \text { is the heat load } \\ F_{s} & \text { is the radiator view factor to space } \\ F_{m} & \text { is the radiator view factor to the lunar surface } \\ \alpha_{R} & \text { is the absorption capability of the radiator } \\ \sigma & \text { is the Stefan-Boltzman constant } \\ A_{R} & \text { is the radiator area } \\ T_{s} & \text { is the space (sink) temperature } \\ T_{m} & \text { is the lunar surface temperature } \\ \epsilon_{m} & \text { is the lunar surface emissivity } \\ \epsilon_{R} & \text { is the radiator emissivity. }\end{array}$


Figure 6.1 shows the relationship between radiator area and temperature for a heat rejection 10 ad of $30 \mathrm{~kW}$, and for the properties and temperatures specified in the legend (the absorption capability and emissions are assumed to be constant). The practical limit on radiator area will result from the requirement that the system be mobile. The likely design approach would be to design the largest practical radiator for a mobile rover and then select and size the heat pump system to accommodate the requisite heat 1 ift. A $30-\mathrm{m}^{2}$ radiator was assumed, based on an overall vehicle length of $10 \mathrm{~m}$ and cylinder width of $3 \mathrm{~m}$. The fabric heat pipe radiator is estimated to have a specific mass of $3 \mathrm{~kg} / \mathrm{m}^{2}$, which gives a radiator mass of $90 \mathrm{~kg}$ (Antoniak et al. 1991).

There have been a number of studies to determine the viability of using heat pumps to upgrade waste heat for space applications in order to reduce

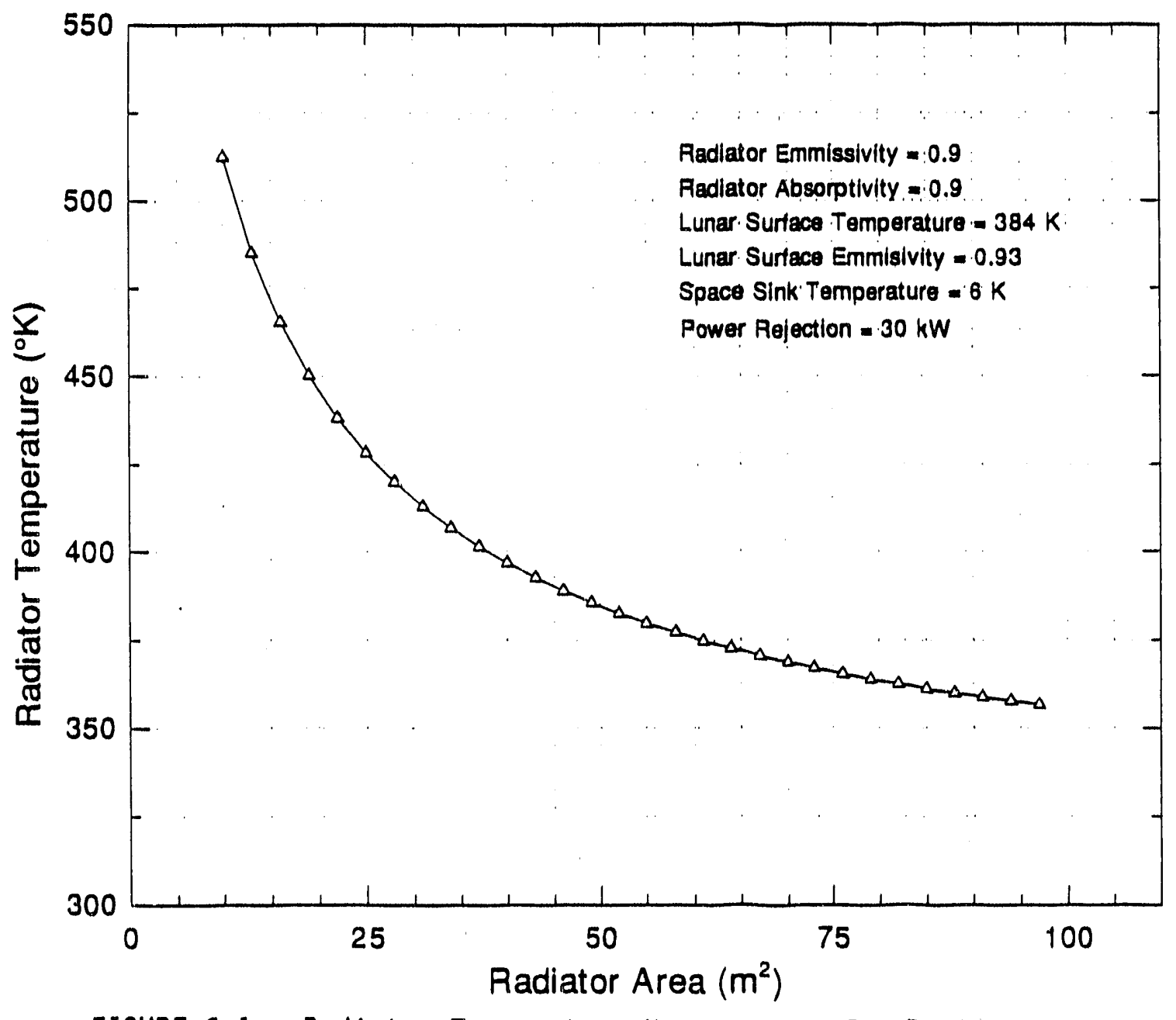

FIGURE 6.1. Radiator Temperature Versus Area for Daytime Operation 
radiator mass and volume (Edwards and Richards 1989; Grossman 1990). These studies have typically looked at orbital applications where a very low radiative heat sink is available. The general consensus is that for these applications a heat pump system would be marginally beneficial.

The high heat sink temperature that a lunar rover would have available, combined with the need to maintain a livable temperature in the module, necessitate the use of an active temperature control system since a shirt-sleeve environment of $300 \mathrm{~K}$ is cooler than the peak heat sink temperature available for an unshaded radiator. From Figure 6.1 a $30-\mathrm{m}^{2}$ radiator is required to reject $30 \mathrm{~kW}$ at $420 \mathrm{~K}$. Radiator shielding and heat storage capacity may be used to mitigate the heat rejection requirements, and to optimize the heat rejection system (Ewart and Clark 1991; Parrish et a1. 1991).

The in-cabin waste heat rejection system would consist of cold plates coupled to a thermal bus to collect waste heat and a heat pump to upgrade the waste heat. The radiator has a selective coating to minimize insolation.

A promising concept for a heat pump system is proposed by Grossman (1989), in which an absorption heat pump using lithium bromide and water is used to upgrade the waste heat. The primary advantage of the absorption cycle is the lack of moving parts (except for a small pumping device). The cycle employs two working flutds. The temperature lift is obtained when one substance is absorbed into the other. Thus the heat pumping action is provided without compression. Grossman estimates $12.2 \mathrm{~kg} / \mathrm{kW}$ specific mass for the generator, evaporator, recuperator, and auxiliary parts of the absorption heat pump.

To upgrade the waste heat to $420 \mathrm{~K}$, the ideal Carnot coefficient of performance is 3.5, (thermal watts moved for each watt consumed by the heat pump). Assuming $60 \%$ of Carnot efficiency is achievable for a real system, the coefficient of performance becomes 2.0. Thus, to reject $20 \mathrm{~kW}$ of cabin waste heat at $300 \mathrm{~K}, 10 \mathrm{~kW}$ is consumed by the thermal management system resulting in $30 \mathrm{~kW}$ radiated at $420 \mathrm{~K}$.

Combining the absorption heat pump with a metal/ceramic fabric heat pipe system will provide a very reliable, relatively low mass heat rejection sys. tem, with a total estimated system mass of $477 \mathrm{~kg}$. 


\subsection{NIGHTTIME OPERATION}

During night operation there is no solar heat radiation and the lunar surface temperature drops significantly, to about $100 \mathrm{~K}$. With this reduced sink temperature, the radiator can operate at a much lower temperature to reject the heat generated in the rover. Figure 6.2 shows the necessary radiator temperature required to dissipate various heat loads versus the lunar surface temperature, which is $375 \mathrm{~K}$ for a $30-\mathrm{kW}$ load. Although the heat pump is used to remove the heat, less power is required than during daytime operation.

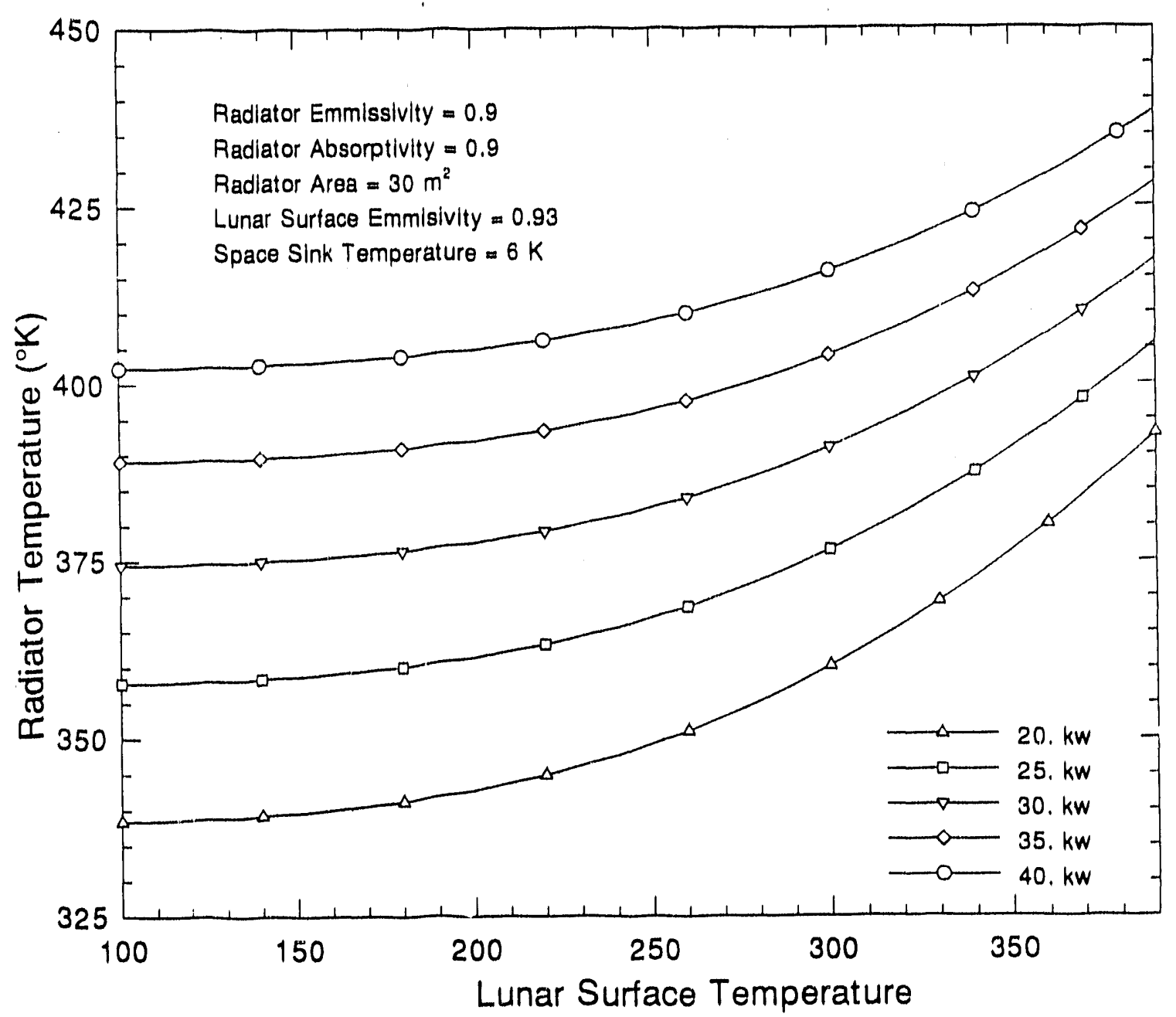

FIGURE 6.2. Radtator Temperature Versus Lunar Surface Temperature 


\subsection{EMERGENCY OPERATION}

During a contingency event, it may be necessary to operate the thermal management system under emergency conditions. Assuming a loss of power, in which the rover must rely solely on emergency energy storage, all nonessential electrical consumption will be curtailed, thereby significantiy reducing the thermal load for the thermal management system. During the day this will not pose a significant problem, since the radiator reaches equilibrium at $300 \mathrm{~K}$ with a heat load of 3 to $5 \mathrm{~kW}$. During the night, very low power dissipation causes the radiator temperature to drop significantly below room temperature. However, if the radiator is isolated from the cabin (by turning off the thermal management fluid loop), sufficient rover insulation would keep the rover warm enough with minimal heat dissipation within the cabin. 


\subsection{MISSION SUMMARY AND HARDWARE REQUIREMENTS}

Lunar rover exploration expeditions are designed to enhance activities conducted at the base. Capability must be provided to permit exploration over a significant distance from the base with equipment for conducting a wide range of research experiments over a period of one lunar day (28 Earth days). To determine the types of experiments and hardware necessary for remote exploration, manifests based on the NASA 90-day study and proposed Space Exploration Initiative science payloads (Budney et a1. 1991) were evaluated to determine the mass, volume, and power requirements for exploration activities.

The scenario assumed for this lunar rover mission provides astronauts the freedom to observe and evaluate phenomena without the need to perform significant manual labor. Small rovers and robots developed during other missions are incorporated and adapted to this exploration mission. Teleoperated mintrovers will be avallabie to collect samples in the vicinity and transport them back to the main rover for analysis.

\subsection{MISSION CLASSIFICATIONS}

Many classes of lunar-based science experiments are planned to invest 1 gate planetary science, astrophysics, space physics, exobiology, ilfe sciences, and resources and materials use. From these experiment classes, planetary science experiments to determine resources and materials use are significantly enhanced by 'jeing conducted as a part of rover expeditions. These investigations are based on evaluation and use of lunar materials. Exploration of large lunar areas, via a series of lunar rover expeditions to characterize the resources and terrain, will significantly improve selection of sites for bases, outposts, and in situ resource development facilities.

\subsubsection{Geophysical Investigations}

These investigations allow astronauts to conduct geologic field work such as mapping and sample collection. Samples will be collected near or on the lunar surface. The amount of supplies necessary for these investigations is based on two fully equipped teams of two astronauts collecting a wide variety of samples in the field, including regolith cores to $10 \mathrm{~m}$ long, rock cores to 
$15 \mathrm{~cm}$ long, bulk rocks, rock fragments, pebbles, sail, and regolith. As a result of these investigations, astronauts will analyze samples and construct geologic field maps.

\subsubsection{Geophysical Ground Sample Archival}

These activities will allow astronauts to return lunar samples to Earth for analysis in terrestrial laboratories or archive unreturned samples on the moon.

\subsubsection{Geophysical Mapping}

These activities allow astronauts to measure a variety of geophysical parameters in the field to provide information to the Earth about the lunar subsurface structure, local gravity and magnetics, and ranging.

\subsubsection{Lunar Environmental Monitoring}

These activities allow continuous monitoring of the lunar atmosphere and geophysical parameters such as heat flow, seismicity, gravity, magnetic field, and space physics conditions.

\subsubsection{Lunar Geoscience Measurements}

These activities will allow detailed assessment of collected samples to perform preliminary analyses or advanced scientific analyses of samples that cannot be returned to Earth in pristine condition.

\subsubsection{Minirover}

The minirover will provide extended mobility to manned exploration. The rover will perform remote sensing and collect and analyze samples. The rover is designed to carry up to $5 \mathrm{~kg}$ of scientific instruments and sampling equipment and travel up to $100 \mathrm{~km}$ on the surface at speeds up to $400 \mathrm{~m} / \mathrm{hr}$.

\subsubsection{Lunar Gas Extraction Experiment}

The purpose of this system is to demonstrate the extraction from and determine the composition of gases emitted from the lunar regolith. The system has the capability to collect gases such as hydrogen, helium, nitrogen, and carbon components for potential use at the lunar outpost. If $\mathrm{He}-3$ is collected, it would be exported to Earth for use as a possible fusion fuel. 


\subsection{HARDWARE REQUIREMENTS}

The components of the payloads for these investigations are summarized in Table 7.1.

\subsection{IN SITU RESOURCE UTILIZATION DEMONSTRATION}

To prepare for in situ resource utilization, small demonstrations must be conducted. The preferred processes to be considered are summarized in Table 7.2. No power requirements were supplied for these activities; however, increased power to the lunar surface could significantly enhance the timing and the magnitude for demonstrating these capabilities. This increased power avallability would enhance developing the manufacturing capacity of the moon to support future space exploration.

IABLE 7.1. Mission-Related Equipment Manifest

$\begin{array}{lrcr}\text { Experiment } & \begin{array}{r}\text { Mass } \\ (\mathrm{kg})\end{array} & \begin{array}{c}\text { Volume } \\ \left(\mathrm{m}^{3}\right)\end{array} & \begin{array}{r}\text { Power } \\ (\mathrm{W})\end{array} \\ \begin{array}{l}\text { Astronaut Field Package } \\ \text { Sample Return Containers }\end{array} & 115 & 0.5 & 890 \\ \text { Geophysics Package } & 145 & 0.3 & \text { N/A } \\ \text { Environmental Station } & 330 & 0.2 & 50 \\ \text { Geoscience Laboratory } & 70 & 0.1 & 80 \\ \text { 10-meter Drill } & 105 & 0.2 & 320 \\ \text { Minirovers (5) } & 305 & 0.2 & 6120 \\ \text { Contingency } & 75 & 0.5 & 20 \\ & 60 & 0.1 & 380 \\ \text { Total } & & & 7860\end{array}$

Source: Budney et a1. 1991 
TABLE 7.2. In Situ Resource Demonstration Activities

Activity

LLOX generator

Metals co-product extractor Carbonyl

Ceramic by-products unit

Volatiles unit
Preferred Process Ilmentie

Consolidate/sinter

Thermal
Application

Water, life support, emergency

repressurization

Powder metallurgy, rods, zeolite

Sintered shades, glass fibers, radiation protection walls

Helium, hydrogen, carbon, nitrogen 


\subsection{CONCLUSIONS}

The present lunar rover study, although using a different power resource approach, has otherwise been quite conventional. That is, it has been implicitly assumed throughout that minimization of average power used will result in the optimal (lowest weight) rover. However, the issue of an optimal rover design acquires a new perspective with the use of power beaming. At a small incremental cost in the beam receiver antenna and related electronics, the rover could potentially have available what is now termed maximum power--but continuously, if required, with no time limit on its use. Given the many unknowns that a iunar rover may encounter during its missions, it would seem prudent to provide it with extended power capabilities and to design for maximum power use to cover unforeseen events and opportunities.

The laser beam-powered rover design presented in this paper has the following specific characteristics:

- With only a total mass of $8000 \mathrm{~kg}$, the rover can take a crew of 4 on 30 day lunar exploration missions, traveling at speeds of up to $10 \mathrm{~km} / \mathrm{hr}$ with very little restrictions with respect to maximum incline and soil composition.

- No constraints on when, how long, or how far the vehicle can travel, within the 30 day mission duration, and no restrictions on day or night operations.

- Drive system has inherent reliability with four separate drive motors, and employs a lightweight fly-by-wire approach.

- An onboard energy storage system uses fuel cells to account for routine power consumption variations, which can be used for backup emergency power.

- Space Station Freedom international racks are used for mounting equipment and instrumentation and for storage. This provides commonality with available flight-qualified hardware.

- Redundant systems are included to ensure crew safety.

- An open life support system is used to minimize mass, complexity, and cost.

- Water, waste water, and methane storage (from atmospheric $\mathrm{CO}_{2}$ removal) are used to augment aluminum radiation shielding. 
- The vehicle is relatively spacious, with $30 \mathrm{~m}^{3}$ of free volume.

- An advanced thermal management system provides the necessary heat rejection with minimum mass.

- A multitude of mission-related devices and instrumentation, rivaling the capability envisioned for an initial lunar outpost, are included in the manifest.

- Mission activities are enhanced by a fleet of battery-powered mini-rovers capable of performing remote exploration missions.

- Abundant energy availability allows potential reduced mass designs for systems and equipment onboard the rover.

Several other features of power beaming that enhance rover capabilities should be mentioned. Because power is not generated onboard the rover, use of a heat pump to increase radiator temperature and effectiveness is a credible option. Furthermore, when rover power requirements are lower than available in the power beam, some form of defocusing could be used to match the incoining power with rover requirements. This would serve to minimize thermal radiator mass and area, as heat only from active components and equipment would need to be rejected.

The power-rich environment available allows the mission planners the flexibility to include a wide variety of missions, which may be both heavy and power intensive. The capabilities of the beam-powered rover are enhanced to the degree that it can outperform even the planned conventional lunar base concepts. Consequently, such a rover would be an excellent candidate for a Rover First architecture, in which the early lunar outpost is a manned rover. 


\subsection{REFERENCES}

Aerospace America. 1988. February issue, p. 35, Washington, D.C.

Antoniak, Z. I., B. J. Webb, and J. M. Bates. 1991. "Testing of Advanced Ceramic Fabric Heat Pipe for a Stirling Engine." Paper AIAA 91-3526, presented at the Conference on Advanced SEI Technologies, September 3-6, Cleveland, Ohio.

Beer, F. P., and E. R. Johnston, Jr. 1962. Vector Mechanics for Engineers: Statics. McGraw-Hill, New York.

Budney, C. J., G. C. Snyder, R. Ionasescu, and R. A. Wallace. 1991. FY91 Final SEI Science Payloads: Descriptions and Delivery Requirements, JPL D7955, Revision A. Jet Propulsion Laboratory, Pasadena, California.

Clark, B. C., J. L. Kalkstein, and S. Meyer. 1991. "The Case for the Methanol Powered Planetary Rover." Paper IAF-91-447, presented at the 43nd Congress of the International Astronautical Federation, October 5-11, Montreal, Canada.

Cohen, M. M. 1985. "Space Station Architecture." Presented at JSC Man/Systems Advanced Development Review Space Station Program Office. Space Human Factors Office, NASA-Ames Research Center, Moffett Field, Cal ifornia.

Davenport, E. W., S. P. Congorn, and B. F. Pierce. 1963. "The Minimum Volumetric Requirements of Man in Space." In Proceedings of American Institute of Aeronautics and Astronautics Summer Meeting, No. 63-250, Los Angeles, California.

De Young, R. J., M. D. Williams, G. H. Walker, G. L. Schuster, and J. H. Lee. 1991. "A Lunar Rover Powered $b_{j}$ ' an Orbiting Laser Diode Array," Space Power, Vol. 10, No. 1 .

Edwards, D. K., and R. F. Richards. 1989. "Optimum Heat Refection Temperatures for Spacecraft Heat Pumps," Journal of Spacecraft and Rockets, Vol. 26, No. 5 .

Ewert, M. K., and C. S. Clark. 1991. "Analysis and Conceptual Design of a Lunar Radiator Parabolic Shade," In Proceedings of the 26th IECEC, Vol. 4., Boston, Massachusetts.

Griffin, B. N. 1991. "A Mobile Habitat for Early Lunar Exploration." Presented at the 42nd Congress of the International Astronautical Federation, Montreal, Canada. IAA-91-628, Boeing Defense \& Space, Advanced Civil Space Systems, Huntsville, Al abama.

Grossman, G. 1990. "Heat Pump Systems for Enhancement of Heat Rejection from Spacecraft," Journal of Propulsion and Power, Vol. 6, No. 5. 
Grossman, G. 1989. "Absorption Heat Pumps for Enhancement of Heat Rejection from Spacecraft," IEEE Paper 899079, Piscataway, New Jersey.

Levinson, A. A., and S. R. Taylor. 1971. Moon Rocks and Minerals. Pergamon Press, New York.

Mason, B., and W. G. Melson. 1970. The Lunar Rocks. Wiley-Interscience, New York.

Means Electrical Cost Data 1990, 13th Annual Edition. 1990. R.S. Means Company, Inc., Kingston, Massachusetts.

Parrish, C. F., R. P. Scaringe, and D. M. Pratt. 1991. "Development of an Innovative Spacecraft Thermal Storage Device," In Proceedings of the 26th IECEC, Vol. 4., Boston, Massachusetts.

Price, S., W. Chun, M. Hammond, and A. Hubert. 1990. "Wheeled Planetary Rover Testbed." SPIE Vol. 1388 Mobile Robots V, p. 550, Bellingham, Washington.

Schock, A., V. Sankarankandath, and M. Shirbacheh. 1989a. "Requirements and Designs for Mars Rover RTGs," In Proceedings of the 24th IECEC, pauer no. 899635, IEEE, Piscataway, New Jersey.

Schock, A., T. Or, and E. Scrabek. 1989b. "Thermal and Electrical Analysis of Mars Rover RTGs," In Proceedings of the 24th IECEC, paper no. 899636, IEEE, Piscataway, New Jersey.

Smith, R. E., and G. S. West. 1982. Space and Planetary Environment Criteria Guidelines for Use in Space Vehicle Development, 1982 Revision (Volume 1), NASA Technical Memorandum 82478, Washington, D.C.

Unique Mobility, Inc. 1991. "DR Series Motor Data Sheet." October 17, Englewood, Colorado.

Williams, R. J., and J. J. Jadwick. 1980. Handbook of Lunar Materials. NASA Reference Publication 1057, Washington, D.C.

Wise, J. A. 1985. The Quantitative Modelling of Human Spatial Habitability. Final Report, NASA Grant No. NAG 2-346, The University of Washington, Seattle, Washington. 


\subsection{BIBLIOGRAPHY}

Aerospace Engineering. October 1989. "Advanced Life Support in Lunar and Mars Missions." pp. 23-27, Washington, D.C.

Bilardo, V. J., Jr. 1990. "The Physical/Chemical Closed-Loop Life Support Research Project." AIAA-90-3729. In Proceedings of the AIAA Space Programs and Technologies Conference, September 25-28, 1990, Huntsville, Alabama. AIAA, Washington, D.C.

Brose, H. F. 1981. "A Regenerative Life Support System for Space Operations Center (SOC)--A Probable First Flight Application. ASME Publication No. 81ENAs-12. American Society of Mechanical Engineers, New York.

Burns, N. M. 1967. Human Behavior During Studies on Manned Lunar Exploration. Systems and Research Center, Honeywell, Minneapolis, Minnesota.

Evanich, P. L, G. E. Voecks, and P. K. Seshan. 1990. "Advanced Life Support Technology Development for the Space Exploration Initiative." AIAA-90-3726. In Proceedings of the AIAA Space Programs and Technologies Conference, September 25-28, 1990, Huntsville, Alabama. AIAA, Washington, D.C.

Hirschbein, M. S. 1991. "Radiation Protection--Exploration Technology Program." Presented at NASA-DOE meetings May 14, 1991. NASA, Office of Aeronautics, Exploration and Technology, Washington, D.C.

Lin, C. H., and M. S. Meyer. 1983. "Systems Engineering Aspects of a Preliminary Conceptual Design of the Space Station Environmental Control and Life Support System." SAE Technical Paper Series, No. 831109. SAE, Warrendale, Pennsylvania.

Ormes, J. F. 1991. "Interplanetary Space Radiation Environment." Presented at NASA-DOE Meetings, May 14, 1991, Washington, D.C. NASA/Goddard Space Flight Center, Greenbelt, Maryland.

Rumme1, J. D. 1991. "NASA's Life Support Programs for Space Exploration." Presented at the NASA-DOE Meeting, May 14, 1991, Washington, D.C. NASA-Ames Research Center, Moffett Field, California.

Space Station Work Package 2 Definition and Preliminary Design Phase. 1986. Habitability/Man Systems Report. SSS 86-0073, Volume 13. NASA Lyndon B. Johnson Space Center, Houston.

Stranger-Johannessen, M. 1991. "Providing a Sound Habitat for Man In Space." Acta Astronautica (23):275-277.

Wieland, P. 1990. "ECLSS Development for Future Space Missions." AIAA 903728. In Proceedings of the AIAA Spare Programs and Technologies Conference, September 25-28, 1990, Huntsville, Alabama. AIAA, Washington, D.C. 
Wydeven, T., and M. A. Golub. 1990. "Generation Rates and Chemical Compositions of Waste Streams in a Typical Crewed Space Habitat." NASA Technical Memorandum 102799. Ames Research Center, Moffett Field, California. 
No. of

Copies

\section{OFFSITE}

12 DOE/Office of Scientific and Technical Information

E. J. Conway

NASA Langley Research Center

High Energy Science Branch

Mail Code: MS-493

Hampton, VA 23665-5225

R. J. De Young

NASA Langley Research Center

High Energy Science Branch

Mail Code: MS-493

Hampton, VA 23665-5225

M. D. Williams

NASA Langley Research Center High Energy Science Branch

Mail Code: MS -493

Hampton, VA 23665-5225
No. of

Copies

ONSITE

DOE Richland Field Office

D. R. Segna

20 Pacific Northwest Laboratory

Z. I. Antoniak

J. A. Bamberger

J. M. Bates

J. C. Becker

E. P. Coomes (5)

J. E. Dagle

R. E. Dodge

L. D. Kannberg

B. L. Mohler

J. A. Wise

Publishing Coordination

Technical Report Files (5) 

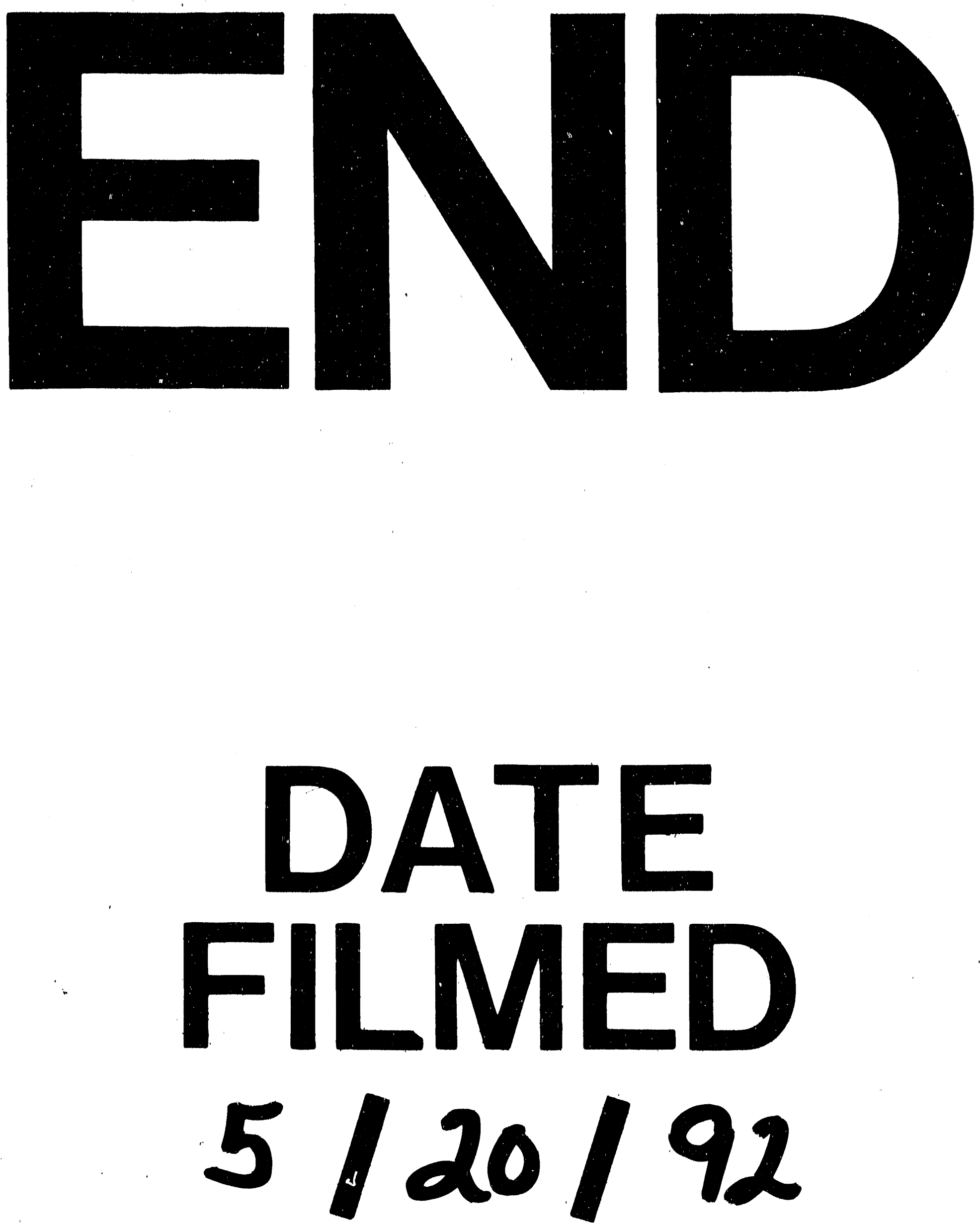
